\title{
Effect of Hypodynamy on Structure and Alkaline Phosphatase Activity of Kidney in Japanese Quails
}

\author{
V. ALMÁS̆IOVÁ, V. CIGÁNKOVÁ, K. HOLOVSKÁ, L. LENHARDT, P. ŠKROBÁNEK , P. MASSÁNYI², \\ M. ZIBRÍN
}

University of Veterinary Medicine, Košice, Slovak Republic

${ }^{1}$ Research Institute of Veterinary Medicine, Ivanka pri Dunaji, Slovak Republic

${ }^{2}$ Slovak Agricultural University, Faculty of Biotechnology and Food Sciences, Nitra,

Slovak Republic

Received June 4, 2007

Accepted April 14, 2008

\begin{abstract}
Almášiová V., V. Cigánková, K. Holovská, L. Lenhardt, P. Škrobánek, P. Massányi, M. Zibrín: Effect of Hypodynamy on Structure and Alkaline Phosphatase Activity of Kidney in Japanese Quails. Acta Vet. Brno 2008, 77: 313-320.

The objective of the study was to observe the effect of experimental hypodynamy simulating weightlessness in space on the structure, ultrastructure and alkaline phosphatase activity of kidney in Japanese quail (Coturnix coturnix japonica). Two days after hatching, the quails were suspended in special shirts below the cage ceiling so their feet did not touch the floor. They could consume food and water ad libitum. Experimental animals were sacrificed after 14, 21, 28, 35, 42, 49 and 56 days of hypodynamy. Birds of the same age, hatched at the same time, and fed the same diet were used as a control. Samples of kidney were processed for light (LM) and transmission electron microscopy (TEM), and alkaline phosphatase (AP) analysis.

Short-term (14-28 days) hypodynamy caused no marked damage to the structure and ultrastructure of kidneys. However, after long-term (35-59 days) hypodynamy, morphological changes were observed in some cells of the proximal and distal tubules. The dying cells in proximal tubules, observed in semi-thin sections by LM, were dark and contained a nucleus of irregular shape. Observation by TEM showed that their nucleus was dark and shrivelled and the electron-dense cytoplasm contained long, dense, rod-shaped mitochondria with thin mitochondrial cristae. Microvilli were present on the apical surface of cells and formed a brush border. Sporadic dying cells were also observed in distal tubules. Large, light vacuoles were found in the cytoplasm of cells of collecting tubules, however, the structure of renal corpuscles and medullary loops remained undisturbed.

Microscopical analysis by means of a direct TUNEL reaction on days 35 to 59 of hypodynamy showed a moderate occurrence of cellular apoptosis in the proximal and distal tubules of experimental Japanese quail. The activity of AP in the brush border of the proximal tubules on days 14-29 of hypodynamy was normal in experimental animals and showed no significant differences in comparison with the control. Between days 35 and 59 of hypodynamy a moderate decrease in the content of AP in experimental animals in comparison with the control $(P<0.01)$ was observed.

Our results indicated that long-term hypodynamy caused apoptosis of some cells in the proximal and distal tubules and therefore had a negative effect on the kidney structure. The occurrence of apoptosis was only sporadic. We presume no negative effect on the kidney function and the Japanese quails are capable of further development under the conditions of prolonged simulated weightlessness.
\end{abstract}

Microgravity, simulated weightlessness, morphology, histochemical analysis

Progress in space research and the probability of future long-term space flights raises interest in their effects on humans and animals (Sychev et al. 2003). Because spatial experiments are demanding and expensive, more frequently we use model experiments on the Earth with the simulation of weightlessness. However, it is not possible to simulate such a unique environment completely. Weightlessness is not complete even in space and because of that we speak about microgravity.

Address for correspondence:

MVDr. Viera Almášiová

University of Veterinary Medicine

Komenského 73, 04181 Košice

Slovak Republic
Phone: +421918967942
Fax: +421552981011
E-mail almasiova@uvm.sk
http://www.vfu.cz/acta-vet/actavet.htm 
Hypodynamy is a method that simulates weightlessness on the Earth under laboratory conditions (Planel 2004). "Rat tail suspension" belongs among model experiments on animals used by NASA, simulating weightlessness in a spacecraft. It was introduced and used by Morey-Holton (1979) and improved later by Morey-Holton and Globus (2002). Animals are suspended by tail and can move only by means of forelimbs. Suspension of animals by means of special flexible shirts is a method used particularly in birds to produce hypodynamy. Birds are suspended below the ceiling of a cage in special net jackets so their feet cannot touch the floor but they can take up feed and drink water. This method was improved and used at the Institute of Animal Biochemistry and Genetics of SAS in Ivanka pri Dunaji (Juráni et al. 1983).

Japanese quail (Coturnix coturnix japonica) is a useful type of bird which is considered prospective for the space programme and, at the same time, is a very suitable object for model experiments. It serves as an inevitable heterotrophic link in the enclosed biological ecosystem of spacecrafts where it should ensure production of animal proteins for astronauts and create psychologically more pleasant environment during long-term space travel. It is a bird with a low body weight, high productive and reproductive abilities, short individual development as well as high tolerance for crowded conditions and adaptability to microgravity (Bod'a 1993).

The aim of the present study was to observe the effect of simulated weightlessness on the structure and alkaline phosphatase activity in kidneys of Japanese quails reared under conditions of long-term experimental hypodynamy. Only few papers have been published about the effect of microgravity or experimental hypodynamy on kidney structure. Most of them bring only knowledge about the influence on kidney function. Our morphological observations of kidneys are original and the published data that could serve for comparison are scarce.

\section{Materials and Methods}

Animals

The experiment was carried out at the Institute of Animal Biochemistry and Genetics of SAS in Ivanka pri Dunaji. Fifty-six newly hatched Japanese quail chicks of both sexes and of a line not selected for hypodynamy were used in the present study. On the second day after hatching, twenty-eight chicks of the experimental group were placed into individual slings suspended by a flexible device in such a way that their legs could not touch the floor. However, the chicks could move about freely by moving their wings. The size of the slings was enlarged from $4 \times 3 \mathrm{~cm} ; 5 \times 4 \mathrm{~cm} ; 6 \times 5 \mathrm{~cm} ; 7 \times 6 \mathrm{~cm}$ and $8 \times 7 \mathrm{~cm}$ to accommodate the growth of the quail. At the same time quail chicks of the control group were placed in a rearing box $0.6 \times 0.6 \times 0.3 \mathrm{~m}$. The birds of the experimental and control group were kept in the respective conditions until day 56 of age in a windowless poultry room with controlled ventilation and electrical heating by infrared lamps. The temperature was adjusted from $35-36^{\circ} \mathrm{C}$ for the first few days after hatching, to $20^{\circ} \mathrm{C}$ in 4 weeks and remained at this level until the end of the experiment. A commercial starter mash HYD-13 and water were available ad libitum; however, food consumption was not measured. The diet was granular and contained $260 \mathrm{~g} \cdot \mathrm{kg}^{-1}$ protein and $11.5 \mathrm{MJ}$ metabolisable energy $\mathrm{kg}^{-1}$. The lighting in the rearing room was left on continuously. This method was developed and used by the Institute of Animal Biochemistry and Genetics of SAS in Ivanka pri Dunaji (Juráni et al. 1983).

Immediately after slaughtering small excisions of the kidney of four control and four experimental animals on days $14,21,28,35,42,49$ and 56 of hypodynamy were removed. Samples of the kidney were processed for light microscopy (LM), transmission electron microscopy (TEM) and histochemical analysis of alkaline phosphatase activity (AP).

The care and use of animals complied with laws and regulations of the Slovak Republic (Korim et al. 2003) and were approved by the Ethics Committee of the Institute of Animal Biochemistry and Genetics.

Light microscopy (LM)

Histological samples of the kidney for LM were processed by a common histological technique. They were fixed in $4 \%$ neutral formaldehyde and embedded in paraffin. Then 5-7 $\mu \mathrm{m}$ thick slides were stained with haematoxylin and eosin and photographed under a light microscope Jenamed.

Transmission electron microscopy (TEM)

Excisions for TEM were fixed by immersion in 3\% glutaraldehyde, postfixed in $1 \%$ OsO (both in $0.15 \mathrm{M}$ cacodylate buffer, $\mathrm{pH} 7.2$ - 7.4), dehydrated in acetone and propylene oxide, and embedded in Durcupan ACM. Ultra-thin sections were cut using an ultramicrotome LKB Nova, double contrasted with uranyl acetate and lead 
citrate and examined under a Tesla BS 500 electron microscope. The semi-thin sections of specimens processed for TEM were stained with toluidine blue and examined under a light microscope.

Confirmation of apoptosis

MEBSTAIN Apoptosis kit Direct (Immunotech, France) was used for immunochemical analysis. After fixation, 3-5 $\mu \mathrm{m}$ thick sections were prepared for staining. The samples were deparaffinized with xylene and ethanol $(100-80 \%)$ and treated with proteinkinase $\mathrm{K}\left(\mathrm{PK}^{+}\right)$. The DNA nick end was labelled, counterstained and mounted. After the procedure the samples were analyzed by means of a fluorescent microscope Leica.

Demonstration of alkaline phosphatase activity (AP)

Kidney samples were frozen in liquid nitrogen. The frozen tissue was cut by a cryostat at $-25^{\circ} \mathrm{C}$ and $7-8$ $\mu \mathrm{m}$ thick slides were transferred onto a supporting glass and air-dried. Demonstration of alkaline phosphatase activity was performed using a modified simultaneous azocoupling method according to Lojda et al. (1979). The incubation medium contained naphtol AS-BI-phosphate (Sigma, Germany), Fast Blue BB (Aldrich, Germany), and veronal acetate buffer $\left(\mathrm{pH}\right.$ 9.2). Incubation was performed at $37^{\circ} \mathrm{C}$ for 10 min using a substrate of a concentration of $2.0 \mathrm{mmol} \cdot \mathrm{l}^{-1}$ and $\mathrm{pH} 8.9$. The enzymatic activity was analysed cytophotometrically with a Vickers $\mathrm{M} 85 \mathrm{a}$ microdensitometer. Statistical evaluation of the results was carried out by one-way analysis of variance ANOVA. The significance of differences between the control and experimental animals was determined by Tukey test.

\section{Results}

\section{LM observation}

On days 14 to 28 of hypodynamy, no damage to the kidney structure was observed and the microscopical structure of kidneys resembled that of control quails (Plate VI, Fig. 1).

On days 35 to 56 of hypodynamy observations of semi-thin sections showed microscopical changes in some cells of proximal and distal tubules (Plate VI, Fig. 2). Sporadic dark stained cells with nuclei of irregular shape were also present. No marked changes were observed in the structure of medullary loops, collecting tubules and renal corpuscles.

\section{TEM observation}

On days 14 to 28 of hypodynamy the cells of proximal tubules had electron-dense cytoplasm (Plate VII, Fig. 3). In the cytoplasm there was a large, round, centrally located nucleus with a prominent nucleolus, abundance of mitochondria of spherical or elongated shape with mitochondrial cristae, cisternae of smooth endoplasmic reticulum and peroxisomes. Some cells contained numerous light vacuoles with flocculent material. The apical part of cytoplasm contained numerous light vacuoles of endocytotic apparatus. High, thin, parallel microvilli were observed on the apical surface of cells.

The cells of distal tubules had moderate electron dense cytoplasm and the nucleus was usually located in the apical part of the cell with few cellular organelles. The cytoplasm contained typical, rod-shaped mitochondria with marked mitochondrial cristae arranged into columns perpendicular to the basal part. In the basal part of cells the basal membrane formed numerous deep invaginations which reached far into the cytoplasm always up to the nucleus. Because the cells were short, distal tubules frequently had a larger luminal diameter than proximal tubules. The cells have no brush border, but a few luminal microvilli were seen. The endocytotic apparatus was not well developed, however, a few vacuoles and lysosomes could be seen within the cells.

The principal and intercalated cells of a cubic shape showing no marked morphological signs of damage formed the wall of cortical collecting tubules. The principal (light) cells contained in pale cytoplasm only a few small, randomly oriented mitochondria and light vacuoles. There were only sporadic small microvilli on the apical surface. The electrondense cytoplasm of intercalated (dark) cells contained more mitochondria located around the nucleus and only sporadic vesicles.

The ultrastructure of renal corpuscles was normal (Plate VII, Fig. 4). The lumen of fenestrated glomerular capillaries contained nucleated erythrocytes. The basal membrane was continuous. The visceral layer of Bowman's capsule consisted of cells - podocytes that formed several long primary cytoplasmic projections - trabeculae. The trabeculae in 
turn branch to form secondary and tertiary processes. These terminal processes are called pedicels. Pedicels of two adjacent cells interlocked and formed gaps through which blood was filtered and glomerular filtrate was produced. Filtration - slit membrane was thinner than a cell membrane and appears to be similar to the diaphragms seen across the pores of fenestrated capillaries. The renal corpuscles contained also mesangial cells located close to the endothelial cells.

On day 35 of hypodynamy the proximal tubules contained also dying cells (Plate VIII, Fig. 5). They had dark, shrivelled nucleus and their electrondense cytoplasm contained long, dense, rod-shaped mitochondria with thin cristae, endocytotic apparatus and peroxisomes. Undamaged microvilli were present on their apical surface. The structure of the light cells was similar to that described above.

On days 42 and 49 of hypodynamy the proximal tubules contained a higher number of dark cells with dark shrivelled nucleus than on day 35 of hypodynamy. Concentrically arranged microvilli could be observed on the apical surface of these cells (Plate VIII, Fig. 6).

On day 56 of hypodynamy some proximal tubules contained clumps of 3-4 dying dark cells. Some tubules showed no marked damage and their structure resembled that described above. Sporadic apoptosis of cells was observed also in distal tubules. The cytoplasm of cells of collecting tubules contained large light vacuoles (Plate IX, Fig. 7).

The proof of apoptosis

Microscopical analysis by means of a direct TUNEL reaction performed on days 35 to 59 of hypodynamy confirmed apoptosis of cells in the proximal and distal kidney tubules (Plate IX, Fig. 8A). The tubular cells in the control group showed no signs of apoptosis, while moderate occurrence of apoptotic cells was recorded in the control group (Plate IX, Fig. 8B).

Enzymatic activity of alkaline phosphatase

On day 14, 21 and 28 of hypodynamy no significant differences in the activity of AP between control and experimental birds were found (Table 1).

Table 1. Enzymatic activity of alkaline phosphatase in brush border of proximal tubules.

\begin{tabular}{|c|c|c|}
\hline \multirow{2}{*}{ Days } & \multicolumn{2}{|c|}{ Activity of AP } \\
\cline { 2 - 3 } & Control & Hypodynamy \\
\hline 14 & $4.05 \pm 0.19$ & $3.98 \pm 0.30$ \\
\hline 21 & $4.27 \pm 0.17$ & $4.22 \pm 0.35$ \\
\hline 28 & $4.67 \pm 0.15$ & $4.48 \pm 0.34$ \\
\hline 35 & $4.77 \pm 0.11$ & $3.88 \pm 0.28^{*}$ \\
\hline 42 & $4.87 \pm 0.19$ & $3.98 \pm 0.29^{*}$ \\
\hline 49 & $4.70 \pm 0.17$ & $3.60 \pm 0.35^{*}$ \\
\hline 56 & $4.68 \pm 0.18$ & $3.78 \pm 0.28^{*}$ \\
\hline
\end{tabular}

On day 35, 42, 49 and 56 of hypodynamy, the content of alkaline phosphatase (AP) in the brush border of the proximal segment of experimental animals was decreased in comparison with the control $(P<0.01)$.

\section{Discussion}

The effect of weightlessness and microgravity on the structure and function of different tissues and organs Values with asterisk denote a significant difference among control and hypodynamy groups of the same age: $* p<0.01$. Values are means $\pm \mathrm{SE}(\mathrm{n}=4$ animals/groups). of various animals has been studied by a number of authors.

Hypodynamy as a useful model simulating microgravity in laboratories represents a potent stressful stimulus which induces several adaptive physiological responses of the organism that serve to maintain its homeostasis. Neuroendocrine response involving the activation of the central regulatory mechanism, changing release of several pituitary hormones, as well as hormones of peripheral glands is prominent among these adaptive responses (Kvetňanský et al. 1991; Macho et al. 1993; Planel 2004). The problem of simulated microgravity has been studied in detail in Japanese quail as a part of the Intercosmos project at the Institute of 
Animal Biochemistry and Genetics of SAS in Ivanka pri Dunaji (Juráni at al. 1980, 1983, 1984, 1991). These authors concluded that the concentration of stressogenic hormones norepinephrine and epinephrine in plasma was increased above the initial level during the whole experiment. Concentration of corticosterone in plasma increased rapidly during the initial phase of hypodynamy and was significantly different from the control group during the whole experiment. The highest values were observed after $1 \mathrm{~h}$ of hypodynamy. They also noted that young quails react more intensively to this non-physiological state (Juráni at. al 1989). Very similar picture of elevation of catecholamines and corticosterone during the stress situation involving hypodynamy in domestic fowl has been reported by Juráni at al (1980, 1983), Harvey et al. (1986), and Satterlee et al. (1988). Short-term microgravity and hypodynamy-induced stress were investigated also from the morphological aspect by Cigánková et al. (2001, 2002 and 2005). They noticed that these specific stressogenic conditions lead to adrenal hypertrophy. But a favourable finding is that long-term hypodynamy resulted in gradual adaptation to relevant stress (Škrobánek et al. 2003), and the corticosterone concentration decreased progressively to normal values on day 60 (Juráni et al. 1983). Also, a line of Japanese quails relatively resistant to hypodynamy was obtained by selective breeding in Ivanka pri Dunaji (Juráni et al. 1988).

Hypodynamy induced changes in the behaviour of quails (Košt'ál et al. 1993) and influenced the consumption of feed and decreased their body weight. Škrobánek et al. (2004, 2005) noted that the body weight and the lengths of femur, tibiotarsus and tarsometatarsus of quails reared in hypodynamy were markedly reduced compared to that of control. The same trend was observed for food consumption and food conversion.

Regarding the skeleton and muscle systems they respond to microgravity by atrophy of the muscles of limbs (Dadasheva and Guryeva 1993; Kočišová et al. 1993, 1996, 2002) and osteoporosis (Černý and Bod'a 1993; Rodionova et al. 2002; Zibrín et al. 2003). Hypodynamy and microgravity induced also some reproductive disorders (Cigánková et al. 1993; Sabo et al. 1996) and morphological changes in enterocytes of the small intestine (Kočišová et al. 1993; Lenhardt et al. 2001) and simultaneously in the liver, lungs and bone marrow (Zibrín et al. 2005).

Cigánková et al. (1993) investigated the influence of microgravity on the structure and ultrastructure of kidneys in 65-70-day-old Japanese quail after a 7-day exposure in space. The conditions in a spacecraft were imitated synchronously on the Earth by creating artificial microgravity. Quails of the same age, reared in a laboratory, served as a control. The authors observed only slight vacuolisation of cytoplasm in the proximal and distal tubules in both the flight and synchronous group and considered the described morphological changes as reversible. They observed that short-term microgravity had no negative effect on the function of kidneys. The present findings agree with those of the above-mentioned study. Zorbas et al. (2001) studied the influence of prolonged 90-day hypokinesia that simulated weightlessness in space and its action on rat kidneys. They observed an increased weight of kidneys and marked morphological changes in the structure of nephrons, particularly in collecting tubules.

The present study investigated the influence of experimental hypodynamy on kidneys of Japanese quail from the morphological aspects. We observed that short-term (14-28 days) hypodynamy caused no marked damage to the structure or ultrastructure of kidneys. Morphological changes were observed only after long-lasting (35-59 days) hypodynamy. Apoptotic cells were found sporadically in the proximal and distal tubules and the cytoplasm of cells of collecting tubules contained large light vacuoles. The structure of renal corpuscles and tubules of the medullary loops remained unchanged. We described the structure and ultrastructure of individual renal cells and provided proof of apoptosis by microscopical analysis employing a direct TUNEL reaction. Histochemical analysis directed on proof of alkaline phosphatase in the brush border of proximal tubules showed 
that the enzymatic activity in experimental birds was decreased only slightly on days 35 to 59 of hypodynamy. The results of our observations indicated that short-term hypodynamy caused no marked morphological changes in kidneys. However, long-lasting hypodynamy had a negative effect on the renal structure.

Long-term hypodynamy caused apoptosis of some cells in the proximal and distal tubules and therefore had a negative effect on the kidney structure. The occurrence of apoptosis was only sporadic, and we propose no negative effect on the kidney function. Japanese quails are capable of further development under the conditions of prolonged simulated weightlessness.

With respect to the previous important facts we make a statement that the observed morphological changes in the Japanese quail kidney may arise not only from microgravity itself but they could be caused by chronic immobilization stress, as well as decreased food consumption, and they secondarily affect the general growth and development of quails. The findings of the present study may serve for the study of adverse effects of hypodynamy on the organism of Japanese quail as well as other animals and humans. However, the structure and function of the avian kidney is different from the mammalian (Černý 2005; Koudela et al. 2003), which must be taken into consideration. Our information may be applied in research of the elimination or reduction of these adverse effects.

\section{Vplyv hypodynamie na štruktúru a aktivitu alkalickej fosfatázy obličiek japonských prepelíc}

Sledovali sme vplyv experimantálnej mikrogravitácie - hypodynamie simulujúcej stav beztiaže v kozme na štruktúru, ultraštruktúru a aktivitu alkalickej fosfatázy obličiek japonských prepelíc (Coturnix coturnix japonica). Dva dni po vyliahnutí boli prepelice zavesené pomocou špeciálnych košiel'ok na strop klietky tak, že sa panvovými končatinami nedotýkali podlahy. Prístup k vode a krmivu mali neobmedzený. Vzorky obličiek pokusných zvierat sme odoberali na 14., 21., 28., 35., 42., 49. a 56. deň hypodynamie. Vtáky rovnakého veku, vyliahnuté v tom istom čase a kŕmené rovnakým krmivom slúžili ako kontrola. Vzorky obličiek boli spracované na svetelnú mikroskopiu (SM), transmisnú elektrónovú mikroskopiu (TEM) a stanovenie aktivity alkalickej fosfatázy.

Krátkodobá (14-28dňová) hypodynamia nespôsobila žiadne výrazné morfologické zmeny v štruktúre a ultraštruktúre obličiek. Pri dlhodobej (35-59dňovej) hypodynamii sme pozorovali morfologické zmeny v niektorých bunkách proximálnych a distálnych kanálikov obličiek. Odumierajúce bunky proximálnych kanálikov boli na polotenkých rezoch tmavé a mali jadro nepravidelného tvaru. Pozorovania TEM ukázali, že ich jadrá boli tmavé a scvrknuté a elektróndenzná cytoplazma obsahovala dlhé, tmavé tyčinkovité mitochondrie s tenkými mitochondriovými priehradkami. Na apikálnom povrchu buniek sa nachádzali mikroklky tvoriace kefkovitý lem. Sporadické odumieranie buniek sme pozorovali aj v distálnych kanálikoch. V cytoplazme buniek zberacích kanálikov sme nachádzali vel'ké svetlé vakuoly, avšak štruktúra obličkových teliesok a dreňových slučiek ostala zachovaná

Mikroskopické analýzy priamou TUNEL reakciou od 35. do 59. dňa hypodynamie odhalili u pokusných prepelíc ojedinelý výskyt apoptóz buniek v proximálnych a distálnych kanálikoch. Aktivita AF v kefkovitom leme proximálnych kanálikov na 14.-28. deň hypodynamie bola u pokusných zvierat normálna. Na 35.-59. deň hypodynamie sme zaznamenali mierny vzrast aktivity alkalickej fosfatázy $\mathrm{v}$ obličkách pokusných prepelíc $\mathrm{v}$ porovnaní $\mathrm{s}$ kontrolou $(P<.0,01)$.

Naše výsledky poukazujú na to, že dlhodobá hypodynamia mala nepriaznivý vplyv na štruktúru obličiek a zapríčinila odumieranie niektorých buniek v proximálnych a distálnych kanálikoch. Výskyt apoptóz bol iba ojedinelý. Nepredpokladáme negatívny vplyv na 
funkciu obličiek a japonské prepelice v podmienkach dlhodobo simulovanej mikrogravitácie môžu rást' a vyvíjat' sa.

\section{Acknowledgement}

The study was supported by the Grant Agency for Science of the Slovak Republic VEGA 1/3495/06.

\section{References}

BOĎA K 1993: The function of the heterotrophic efficiency organism as link of the food chain of the closed ecosystem in microgravity conditions. Acta Vet Brno 62 (Suppl. 6): S91-S94

CIGÁNKOVÁ V, KOČIŠOVÁ J, BOĎA K, TOMAJKOVÁ E, DADASHEVA OA 1993: Morphological changes in tissue of the testes and kidneys in Japanese quail exposed to microgravity. Acta Vet Brno 62 (Suppl. 6): S69-S71

CIGÁNKOVÁ V, ZIBRÍN M, KOČIŠOVÁ J, SABO V, BOĎA K, DADASHEVA OA, GURYEVA TS 2001: Histological changes in the adrenal glands of newly hatched Japanese quail chicks during a short stay on the orbital station Mir. Folia Vet 45 (Suppl.): 36-40

CIGÁNKOVÁ V, ZIBRÍN M, KOČISSOVÁ J, TOMAJKOVÁ E, SABO V, BOĎA K, DADASHEVA OA, GURYEVA TS 2002: Morphological changes in the adrenals of Japanese quail chickens hatched out in microgravity. Aviakosm Ekolog Med 36: 29-32

CIGÁNKOVÁ V, ZIBRÍN M, HOLOVSKÁ K 2005: Effect of long-term experimental hypodynamy on the adrenal glands of Japanese quails: An ultrastructural study. Bull Vet Inst Puławy 49: 449-453

ČERNÝ H, BOĎA K 1993: Microscopic picture of skeleton ossification in Japanese quail in the early postincubation period after a short exposure to microgravity. Acta Vet Brno 62 (Suppl. 6): S49-S50

ČERNÝ H 2005: Urogenital System. In: Anatomy of Domestic Birds (Czech). Metoda spol. s. r. o., Brno, pp. $277-288$

DADASHEVA OA, GURYEVA TS 1993: Bone and muscular tissue development in embryos and newly hatched quail incubated in weightlessness. Acta Vet Brno 62 (Suppl. 6): S51-S59

HARVEY S, SCANES CG, BROWN KI 1986: Adrenals. In: STURKIE PD (Ed.): Avian Physiology. $4^{\text {th }}$ ed. Springer-Verlag, New York, pp. 479-493

JURÁNI M, NVOTA J, VÝBOH P, BOĎA K 1980: Effect of stress on plasma catecholamines in domestic birds. In: USDIN E, KVETŇANSKÝ R, KOPIN IJ (Eds.): Catecholamines and Stress Recent Advances. Elsevier/ North Holland Inc., pp. 285-290

JURÁNI M, VÝBOH P, LAMOŠOVÁ D, BAROŠKOVÁ Ž, SOMOGYIOVÁ E, BOĎA K, GAŽO M 1983: The effect of a 90-day hypodynamy on the neurohumoral system, egg laying and metabolism of proteins in Japanese quail. Physiologist 26 (Suppl): 145-148

JURÁNI M, KISS A, KVALTÍNOVÁ Z, SOMOGYIOVÁ E, KVETŇANSKÝ R 1984: Effect of acute stress on catecholamine content in the hypothalamic nuclei of Japanese quail. Br Poult Sci 25: 91-98

JURÁNI M, BOĎA K, KOŠTÁL L, SOMOGYIOVÁ E, LAMOŠOVÁ D, VÝBOH P, AMBRUŠ B, BAUMGARTNER J 1988: Selection of Japanese quail line resistant to hypodynamy. Physiologist 31: $140-141$

JURÁNI M, HARVEY S, VÝBOH P, LAMOŠOVÁ D, SOMOGYIOVÁ E 1989: Response of neurohumoral system of Japanese quail during hypodynamy. In: BOĎA K (Ed.): Endocrinology of farm animals. Proceedings of the II. International Symposium on Farm Animal Endocrinology. March 1989. Smolenice Castle, pp. 353-365

JURÁNI M, BOĎA K, VÝBOH P, ZEMAN M, LAMOŠOVÁ D, SOMOGYOVÁ E, KOŠŤÁL L, BAUMGARTNER J 1991: An endocrine response to short-term hypodynamy in Japanese quail selected for resistance to hypodynamy. Physiologist 34 (Suppl.): 129-131

KOČIŠOVÁ J, CIGÁNKOVÁ V, BOḊA K, TOMAJKOVÁ E, DADASHEVA OA 1993: Ultrastructure of small intestine enterocytes of Japanese quail after exposure to microgravity. Acta Vet Brno 62 (Suppl. 6): S81-S82

KOČIŠOVÁ J, SABO V 1996: Effect of hypodynamy on striated muscle in Japanese quail. III International avian microgravity and life support system. Workshop, Košice 29. 9. - 2. 10. 1997

KOČIŠOVÁ J, CIGÁNKOVÁ V, ZIBRÍN M, TOMAJKOVÁ E, SABO V, BOĎA K, DADASHEVA OA, GURYEVA TS 2002: Morphological study of gastrocnemius muscle in Japanese quail chicks hatched out in space flight. Aviakosm Ekolog Med 36: 6-9

KORIM P, BUGARSKÝ A, JURIŠ P, HADBAVNÝ M, KORIMOVÁ M 2003: Protection of experimental animals. Slov Vet J 28: 10-12

KOŠŤÁL L, JURÁNI M, BOĎA K, SHEPELEV YE YA, GURYEVA TS, SABO V, DADASHEVA OA 1993: Behaviour of Japanese quail in microgravity on the Mir orbital station. Acta Vet Brno 62 (Suppl. 6): S65-S67

KOUDELA K 2003: Excretion. In: JELINEK P, KOUDELA K (Eds.): Physiology of Domestic Animals. MZLU, Brno, pp. 189-203

KVETNAANSKÝ R, NOSKOV VB, BLAŽIČEK P, GHARIB C, POPOVA IA, GAUQUELIN G, MACHO L, GUELL A, GRIGORIEV AI 1991: Activity of the sympathoadrenal system in cosmonauts during 25-day space flight on station Mir. Acta Astronaut 23: 109-116 
LENHARDT L, CIGÁNKOVÁ V, ZIBRÍN M, KOČIŠOVÁ J, TOMKOVÁ I, SABO V, BOĎA K, DADASHEVA OA, GURYEVA TS, MOZES Š 2001 : Functional development of small intestine of Japanese quail hatched on Mir orbital station. Acta Vet Brno 70: 127-131

LOJDA Z, GROSSRAU R, SCHIBLER TH 1979: Enzyme Histochemistry. Springer-Verlag, Berlin, pp. 59-70

MACHO L, JEŽOVÁ D, JURČOVIČOVÁ J, KVETŇANSKÝ R, VIGAS R, SEROVA LB 1993: Effect of space flight on the development of endocrine functions in rats. Endocr Regul 27: 17-22

MOREY-HOLTON ER 1979: Spaceflight and bone turnover. Correlation with a new rat model of weightlessness. Bioscience 3: 168-172

MOREY-HOLTON ER, GLOBUS RK 2002: Hindlimb unloading rodent model: Technical aspects. J Appl Physiol 92: 1367-1377

PLANEL H 2004: Space and Life. Introduction to Space Biology and Medicine. Gravity and Weightlessness CRC Press, Boca Raton-London-New York-Washington D.C., pp. 27-34

RODIONOVA NV, OGANOV VS, ZOLOTOVA NV 2002: Ultrastructural changes in osteocytes in microgravity conditions. Adv Space Res 30: 765-770

SABO V, BOĎA K, CHRAPPA V, ŠKROBÁNEK P, VÝBOH P 1996: Effects of hypodynamy on the reproductive functions of Japanese quail. Acta Vet Brno 65: 65-72

SATTERLEE DG, JOHNSON WA 1988: Selection of Japanese quail for contrasting blood corticosterone response to immobilization. Poult Sci 67: 25-32

SYCHEV VN, LEVINSKIKH MA, SHEPELEV YE YA, PODOLINSKII IG 2003: Biological processes of the human environment regeneration within the Martian crew life support systems. Aviakosm Ekolog Med 37: 64-70

ŠKROBÁNEK P, HRANČOVÁ M 2003: Adaptability of Japanese quail chicks to conditions of simulated weightlessness. Acta Vet Brno 72: 347-351

ŠKROBÁNEK P, HRBATÁ M, BARANOVSKÁ M, JURÁNI M 2004: Growth of Japanese quail chicks in simulated weightlessness. Acta Vet Brno 73: 157-164

ŠKROBÁNEK P, BARANOVSKÁ M, JURÁNI M, ŠÁRNIKOVÁ B 2005: Influence of simulated microgravity on leg bone development in Japanese quail chicks. Acta Vet Brno 74: 475-481

ZIBRÍN M, BOĎA K, CIGÁNKOVÁ V, KOČIŠOVÁ J, TOMAJKOVÁ E, KOMOROVÁ T, SABO V, PIVKO J 2003: Long-term experimental hypodynamy affects the structure of spongy bone and osteoclasts in Japanese quail. Acta Vet Brno 72: 143-149

ZIBRÍN M, CIGÁNKOVÁ V, KOČIŠOVÁ J, TOMAJKOVÁ E, KOMOROVÁ T, BOĎA K, WEISMANN P, DADASHEVA OA, GURYEVA TS 2005: Effect of short-term space flight on structure of liver, lungs, bone and bone marrow of Japanese quail hatched on orbital station Mir. Acta Vet Brno 74: 167-174

ZORBAS YG, AFONIN VB, CHARAPAKHIN KP, TSIAMIS CB, DENOGRATOV SD 2001: Measurements of nuclear size in collecting tubules of the kidney of rats during prolonged hypokinesia and ambulatory conditions. Int Urol Nephrol 33: 423-430 
Plate VI

Almášiová V. et al.: Effect of ... pp. 313-320

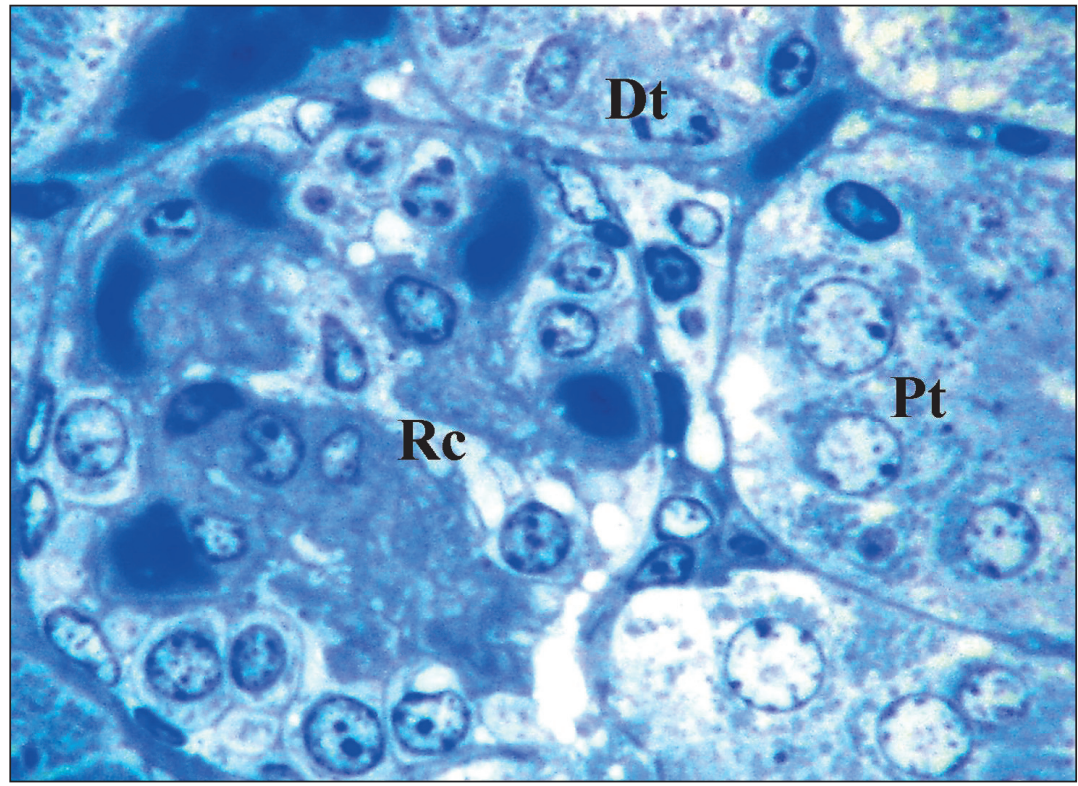

Fig. 1. Light micrograph of renal corpuscle and parts of proximal and distal tubules on day 21 of hypodynamy - semithin section

$\mathrm{Rc}$ - renal corpuscle, $\mathrm{Pt}$ - proximal tubule, Dt - distal tubule Magnification $\times 1000$

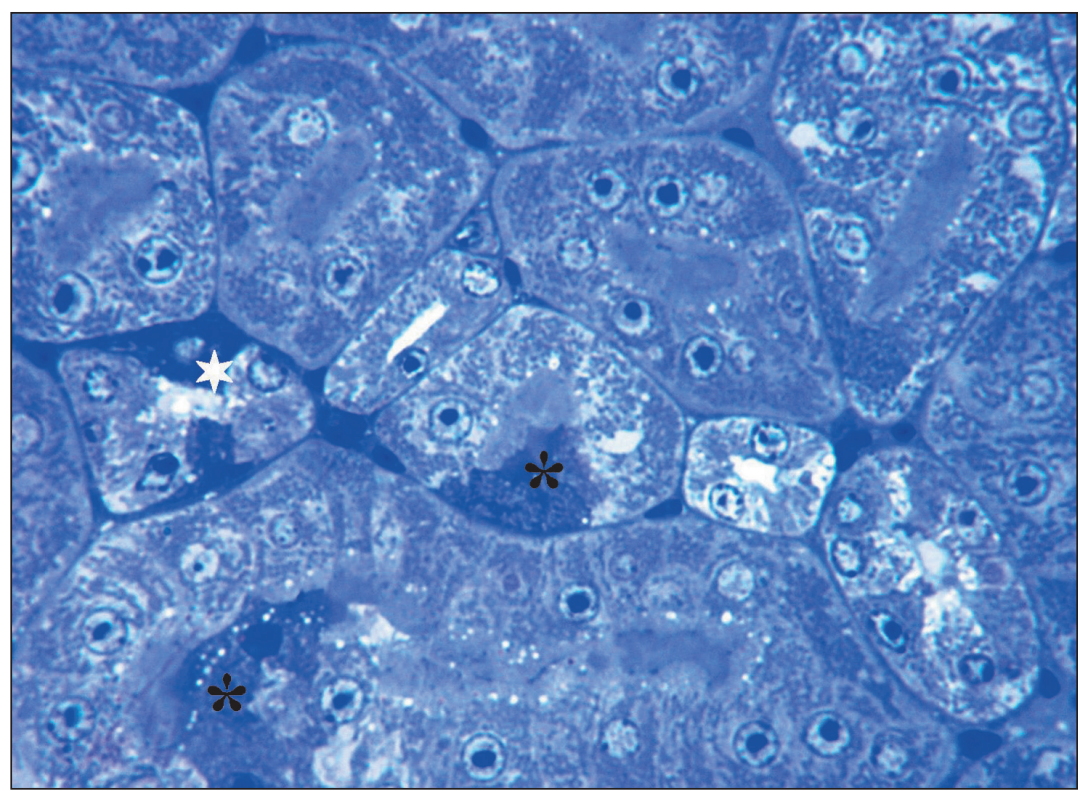

Fig. 2. Light micrograph of the kidney with dark blue apoptotic cells of proximal and distal tubules on day 35 of hypodynamy - semithin section asterisks - apoptotic cells Magnification $\times 400$ 


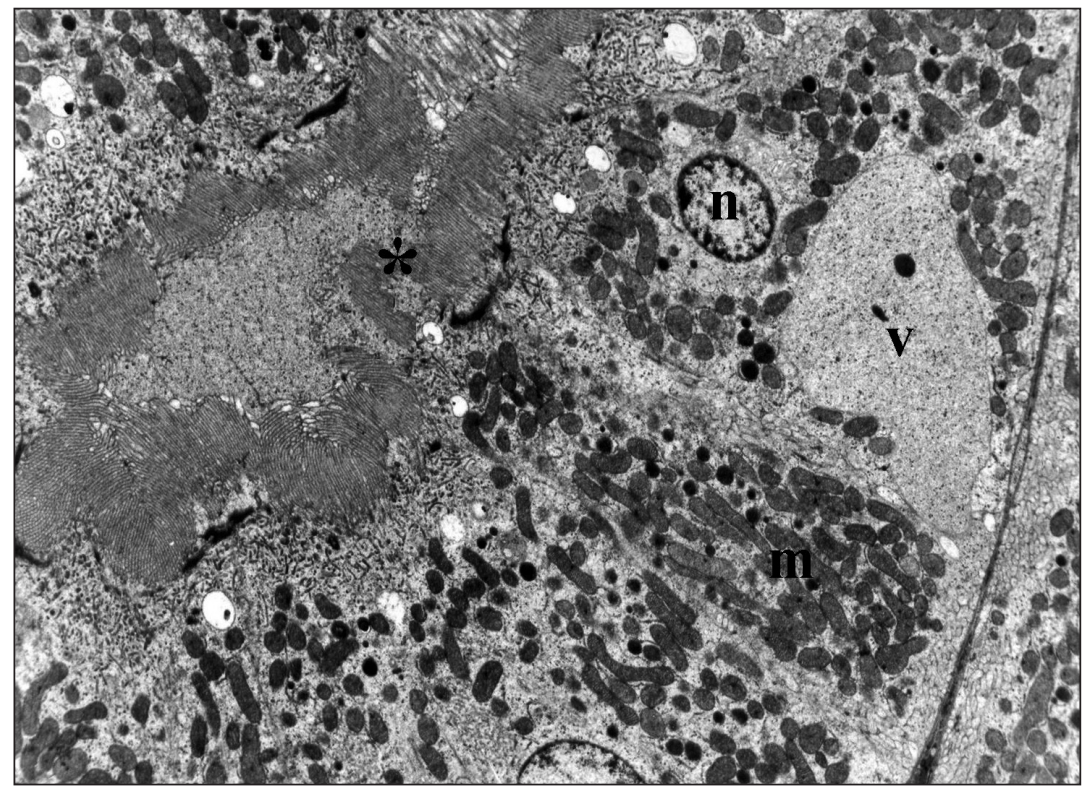

Fig. 3. Electron micrograph of the proximal tubule without morphological changes on day 28 of hypodynamy

$\mathrm{n}$ - nucleus, $\mathrm{m}$ - mitochondriae, $\mathrm{v}$ - vacuoles, asterisk - microvilli

Magnification $\times 3100$

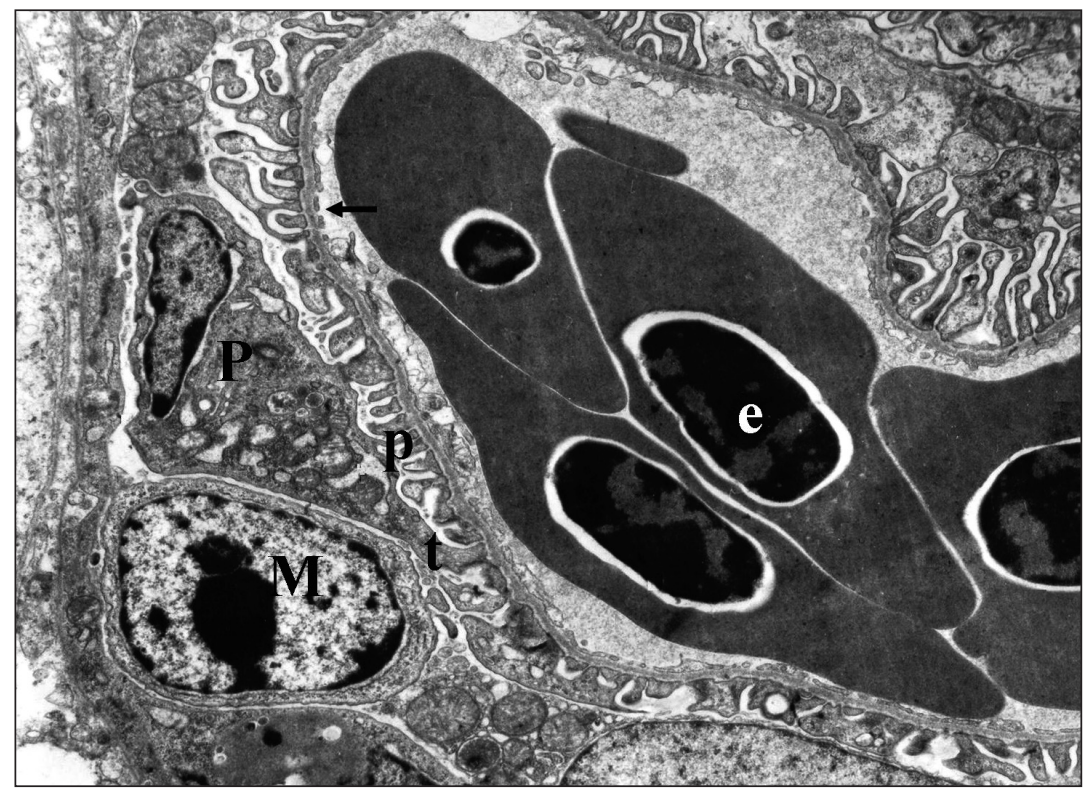

Fig. 4. Electron micrograph of a part of renal corpuscle with erythrocytes in fenestrate capillary on day 21 of hypodynamy

e - erythrocytes, $\mathrm{P}$ - podocyte, $\mathrm{t}$ - trabeculae, $\mathrm{p}$ - pedicles, $\mathrm{M}$ - mesangial cell, arrow - fenestrae

Magnification $\times 7700$ 


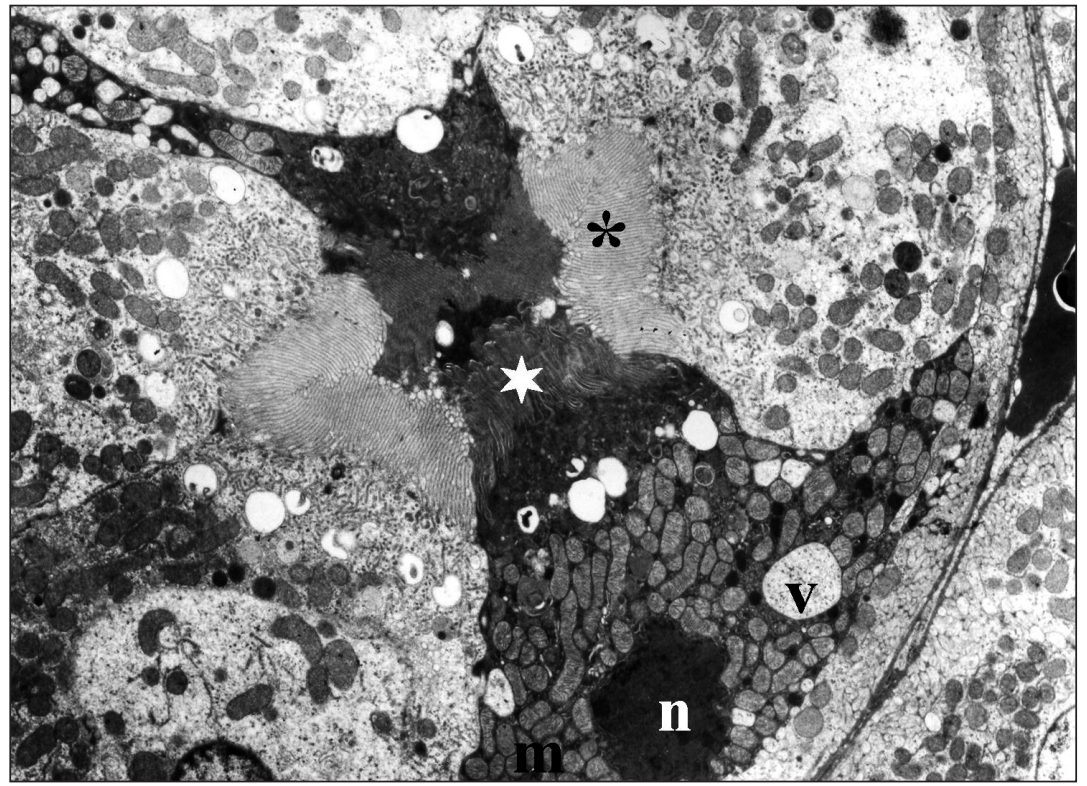

Fig. 5 Electron micrograph of the proximal tubule with dark cells on day 35 of hypodynamy $\mathrm{n}$ - nucleus, $\mathrm{m}$ - mitochondriae, $\mathrm{v}$ - vacuoles, asterisks - microvilli Magnification $\times 3100$

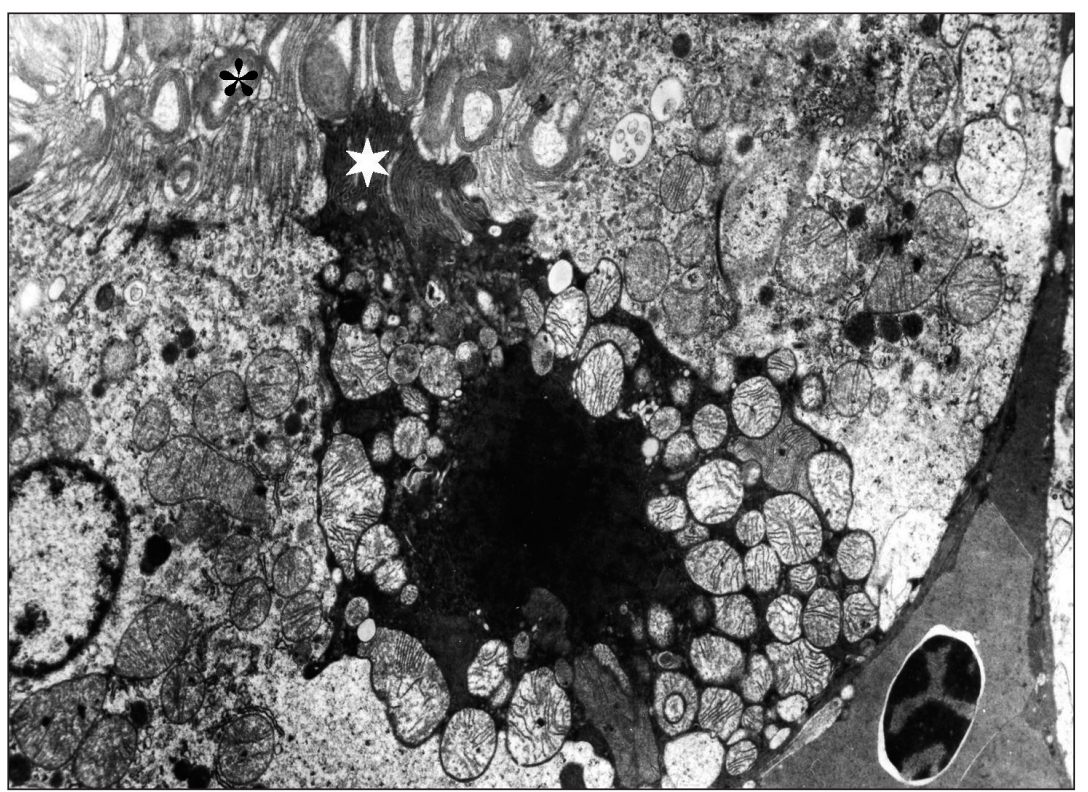

Fig. 6 Electron micrograph - concentrically arranged microvilli on the apical surface of the cells of proximal tubule on day 49 of hypodynamy asterisks - microvilli Magnification $\times 6100$ 


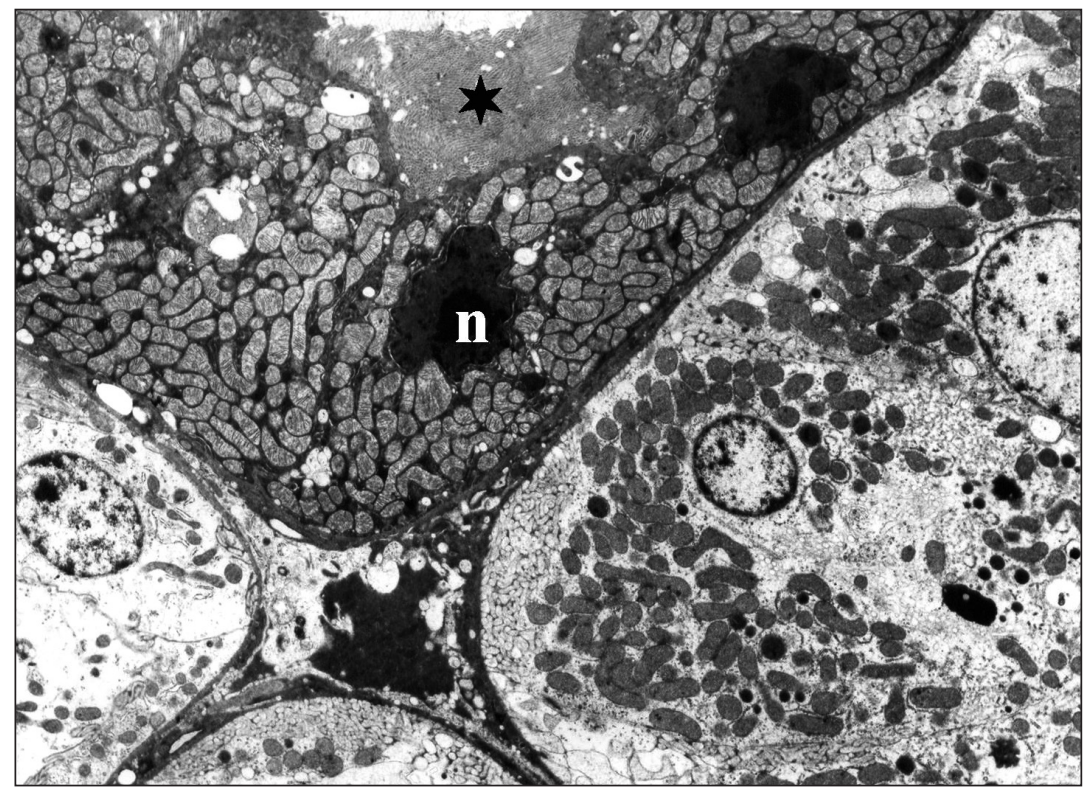

Fig. 7 Electron micrograph of part of proximal tubule which contain the clump of 3 - 4 dying dark cells, and part of proximal tubule showed no marked damage on day 56 of hypodynamy $\mathrm{n}$ - dark shriveled nucleus, asterisk - microvilli Magnification $\times 4100$

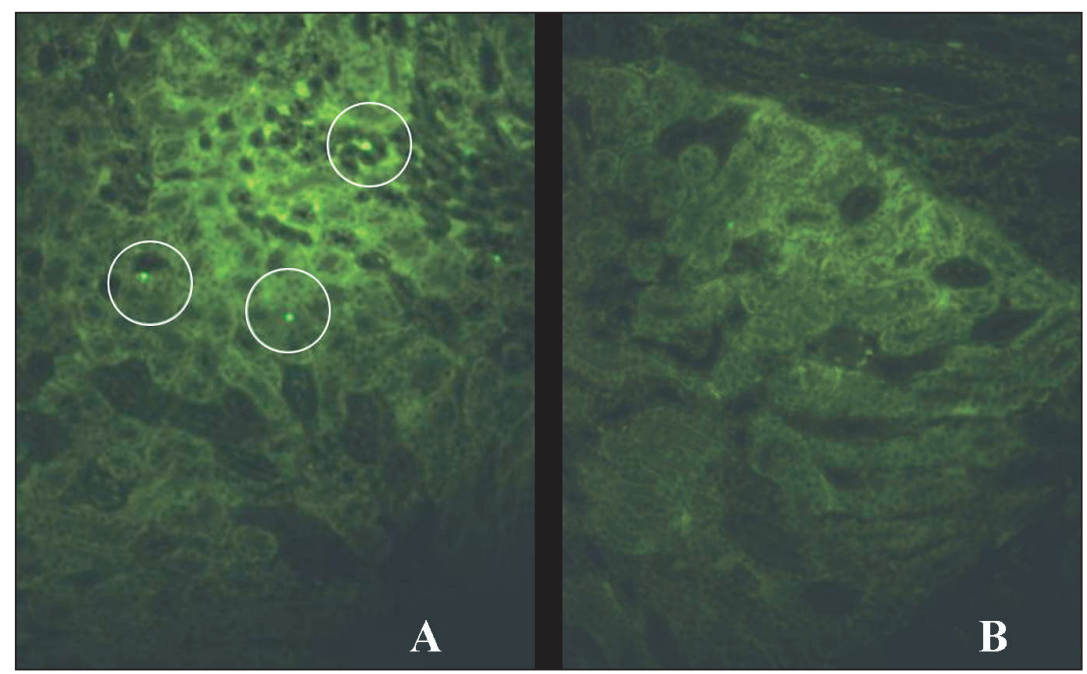

Fig. 8 Immunohistochemical analysis detected an increased apoptosis in the cells of proximal and distal tubules on day 42 of hypodynamy (A) in comparison with the control (B) 